\title{
CZU: [634.848.1:634.849]:57.047(478)(043.2)～https://doi.org/10.53040/gppb7.2021.36 COMPUȘII CHIMICI VOLATILI ȘI NOILE GENOTIPURI DE VIȚĂ-DE-VIE
}

\author{
Gaina Boris ${ }^{1}$, Alexandrov Eugeniu ${ }^{2}$ \\ ${ }^{1}$ Academia de Științe a Moldovei, e-mail: borisgaina17@gmail.com \\ ${ }^{2}$ Institutul de Genetică, Fiziologie și Protecție a Plantelor, Chișinău, Republica Moldova \\ e-mail: eugeniu.alexandrov@igfpp.md
}

\begin{abstract}
In the process of development and ripening of berries, depending on fluctuations in climatic factors, an aroma characteristic of the genotype of grapevine is formed, and as a result of processing the bunches, a bouquet of young wine is formed. Grapevine berries contain, for the most part, the same aromatic chemical compounds, however, the specific aroma is due not only to their different mass concentration, but also to their ratio in the aromatic complex of each genotype. The specific shade of aromas of a particular genotype and the accent of aromas of a particular genotype depends to a greater extent on the transmission of hereditary traits from parental pairs of crossing, the degree of ripening of berries, the phytosanitary level of plantings and on the influence of factors of the growing environment. The purpose of this study is to determine and comparative analysis of aromatic compounds in the berries of the rhizogenic interspecific genotype of grapevine Amethyst with the same complex of volatile compounds of the classic varieties Feteasca Neagră, Cabernet-Sauvignon, Malbec.
\end{abstract}

Key words: grapevine, adaptability, berries, aromatic compounds, genotype.

\section{Introducere}

Aroma specifică genotipului de viță-de-vie este redată de cantitatea și calitatea compușilor chimici volatili din bace. În faza de dezvoltare și maturare a bacelor se formează aromele primare, apoi în rezultatul procesării și fermentării mustuielii se formează compușii aromatici secundari și în final pe parcursul perioadei păstrării produsului derivat (vinul) în butoaie din lemn sau în vase din inox (maturare) se formează compușii aromatici terțiari, care la rândul lor definitivează procesul de formare a buchetului produsului derivat $[5,9]$. Compușii chimici aromatici din bacele de viță-de-vie depind de gradul de maturare a acestora, de starea fitosanitară și factorii pedo-climatici, tehnologia de cultivare şi factorul decisiv în moştenirea caracterelor de la formele parentale $[2,3,8]$.

Scopul prezentului studiu constă în determinarea cantitativă și calitativă a compușilor chimici aromatici, analiza comparată a acestor compuși chimici a bacelor genotipului interspecific de viță-de-vie Ametist și genotipurilor intraspecifice de viță-de-vie, ca: Feteasca neagră, Cabernet-Sauvignon şi Malbec.

\section{Materiale si metode}

In calitate de obiect de studiu au servit bacele de culoare albastru-violet a genotipului interspecific de viță-de-vie Ametist (Vitis vinifera L. x Muscadinia rotundifolia Michx.) [1] și bacele genotipurilor intraspecifice de viţă-de-vie Feteasca neagră, Cabernet-Sauvignon și Malbec. Roada anului 2020, cu o productivitate de 10 tone per hectar.

Determinarea compușilor volatili cu potențial aromatic a fost realizată cu ajutorul sistemului de analiză Shimadzu GC și spectrometrului de masă GC/MS-QP2010 Plus, dotat cu complex de injectare a probelor AOC-500 (cu respectarea prevederilor Hotărârii Comisiei Consiliului Europei №. 606/2009 din 10.07.2009). Pentru micro-extragere în faza solidă a fost utilizat Carboxen PDMS cu dimensiunile de 100 $\mu \mathrm{M}$, cu ajutorul căruia a fost extrași compușii volatili în concentrație de 10 ppv şi $10 \mathrm{ppm}$. Analiza datelor a fost executată cu ajutorul sistemului Software GC/MS Solution (Shimadzu), dotat cu SCAN/SIM (FASST) [2, 4]. Alte însușiri fizico-chimice ale bacelor și produselor derivate obținute au fost determinate cu ajutorul metodelor aprobate de Oficiul Internaţional al Viei și Vinului $[2,6,10]$.

\section{Rezultate și discuții}

În procesul de evoluție al organismelor s-au format anumite calităţi individuale, care permit a reacționa într-un mod specific la anumite condiții ale mediului înconjurător. Cantitatea și calitatea compușilor aromatici din bacele de viță-de-vie într-o măsură anumită depind de calitatea factorilor mediului înconjurător. Bacele de viță-de-vie conțin, în mare măsură, unii și aceiași compuși chimici aromatici, însă nuanța aromei specifice este redată de cantitatea și calitatea compușilor chimici a genotipului. 
Vinul reprezintă un produs derivat cu o gamă foarte variată de nuanțe de arome de fructe și flori, greu de descris și de clasificat. Dacă nuanțele de arome de fructe pot fi relativ ușor de determinat, apoi cele florale sunt foarte numeroase, diferența între ele este foarte mică și în final este foarte dificil a întocmi o notă organoleptică obiectivă.

Compușii chimici volatili în dependență de caracterul aromelor formează anumite grupuri de bază de arome, care în final se percep în produsul derivat obținut: florale, vegetale, de fructe. Aromele florale din bacele de viță-de-vie sunt datorate compușilor terpenici (terpenoli), așa ca: linalool, geraniol, nerol, terpineol, citronelol, hotrienol.

În baza analizelor chimice a sucului bacelor genotipului interspecific de viţă-de-vie Ametist, constatăm că: linalool este prezent în cantitate de $21,4 \mu \mathrm{g} / \mathrm{dm}^{3}$, geraniol $-9,6 \mu \mathrm{g} / \mathrm{dm}^{3}$, nerol $-7,5 \mu \mathrm{g} / \mathrm{dm}^{3}$, terpineol $-6,3 \mu \mathrm{g} / \mathrm{dm}^{3}$, citronelol $-11,4 \mu \mathrm{g} / \mathrm{dm}^{3}$. Pragul de percepţie a acestor compuşi aromatici este destul de mic, care în final formează arome cu nuanţe florale (tab.1.).

Compuşii chimici aromatici din bacele de viţă-de-vie reprezintă un element esenţial care formează buchetul produselor derivate obţinute ca rezultat al efectului sumar al aromelor formate din compuşii sintetizaţi de către microorganisme în procesul de fermentare $[4,7]$.

Utilizând metode şi echipament știinţific contemporan, a fost posibil a urmări acumularea compuşilor aromatici în bacele de viţă-de-vie în rezultatul maturării şi apoi, procesul de trecere a acestora în mustuială şi vin. Lucrările științifice recente ale cercetătorilor oenologi şi oenochimişti de la Universitatea din California, au demonstrat rolul principal al raportului şi influenţei a compuşilor aromatici esenţial din vin, precum şi interacţiunea dintre aceştia în definitivarea nuanţelor diferitor tipuri de vin.

Tabelul 1. Compuși chimici care formează arome cu nuanțe florale

\begin{tabular}{|c|c|c|c|c|c|}
\hline \multirow{2}{*}{ Genotipul } & \multicolumn{5}{|c|}{ Compuși chimici } \\
\cline { 2 - 6 } & Nerol, $\mu \mathrm{g} / \mathrm{dm}^{3}$ & $\begin{array}{c}\text { Linalool, } \\
\mu \mathrm{g} / \mathrm{dm}^{3}\end{array}$ & $\begin{array}{c}\text { Alfa-tirpeniol, } \\
\mu \mathrm{g} / \mathrm{dm}^{3}\end{array}$ & $\begin{array}{c}\text { Geraniol, } \\
\mu \mathrm{g} / \mathrm{dm}^{3}\end{array}$ & $\begin{array}{c}\text { Citronelol, } \\
\mu \mathrm{g} / \mathrm{dm}^{3}\end{array}$ \\
\hline Ametist & $7,5+/-0,3$ & 21,4 & 6,3 & 9,6 & 11,4 \\
\hline Feteasca Neagră & $6,9+/-0,4$ & 20,1 & 4,9 & 8,8 & 7,3 \\
\hline Cabernet-Sauvignon & $6,3+/-0,31$ & $4,2+/-0,11$ & $7,2+/-0,7$ & $11,7+/-0,09$ & $17,9+/-0,07$ \\
\hline Malbec & $2,9+/-0,14$ & $3,8+/-0,09$ & $5,4+/-0,7$ & $7,8+/-0,9$ & $14,4+/-0,03$ \\
\hline Pragul de percepție & 22 & 25 & 300 & 30 & 18 \\
\hline
\end{tabular}

Un criteriu de bază care determină rolul compuşilor aromatici din vin îl reprezintă „concentraţia pragului de perceptie", de care depinde perceperea unuia sau altui compus chimic în vin, sau fiind determinat cantitativ, însă pe cale organoleptică nu poate fi determinat. Deci, într-un vin în cazul când acetatul de etil este prezent în cantitate de $50 \mu \mathrm{g} / \mathrm{dm}^{3}$ se constată prezența nuanțelor fructelor de mere şi pere, iar în cazul când acetatul de etil este în limita de $150 \mu \mathrm{g} / \mathrm{dm}^{3}$ - aceste nuanţe nu se manifestă. Aceste nuanţe ale aromelor reprezintă rezultatul influenței altor compuși chimici din vin, la momentul actual au fost determinate circa 500 de compuși chimici din această grupă.

Analiza cantitativă şi calitativă comparată a unor compuşi chimici aromatici permite a constata prezența în concentraţii mari în coaja bacelor a aşa compuşi ca cis-3-ghexel-1-ol (la genotipul Ametist în cantitate de $31,3+/-0,21 \mu \mathrm{g} / \mathrm{dm}^{3}$ şi la soiul Cabernet-Sauvignon de $66,9+/-0,08 \mu \mathrm{g} / \mathrm{dm}^{3}$, care redă nuanţe ierbacee sau de fructe nemature. Un compus esenţial este linaloolul, care este prezent la Feteasca neagră în cantitate de $20,1+/-0,6 \mu \mathrm{g} / \mathrm{dm}^{3}$ şi la Cabernet-Sauvignon de $42,0+/-0,11 \mu \mathrm{g} / \mathrm{dm}^{3}$, care formează nuanţe cu arome de basilic sau levănţică. Însă, cantităţi destul de sporite se constată de no-diendiol 1, la genotipul Ametist este de $113,4+/-0,007 \mu \mathrm{g} / \mathrm{dm}^{3}$ şi la soiul Malbec $-78,8 \mu \mathrm{g} / \mathrm{dm}^{3}$. De asemenea, este necesar a se menţiona că dietilsuccionat este prezent în cantitate de $550,3+/-0,029 \mu \mathrm{g} / \mathrm{dm}^{3}$ la soiul Malbec şi $447,0+/-0,03 \mu \mathrm{g} / \mathrm{dm}^{3}$ la soiul Ametist, iar gama-butirolacton în bacele de Ametist este prezent în cantitate de $1139,0+/-0,029 \mu \mathrm{g} / \mathrm{dm}^{3}$ și la soiul Malbec de $970,0+/-0,019 \mu \mathrm{g} / \mathrm{dm}^{3}$.

Evaluând unii indici chimici ai vinului din soiul Ametist, a fost constatat că: suma compușilor fenolici constituie $987 \mu \mathrm{g} / \mathrm{dm}^{3}$, ph-ul - 3,6, aciditatea titrabilă $-5,3 \mathrm{~g} / \mathrm{dm}^{3}$, aciditatea volatilă $-0,46 \mathrm{~g} / \mathrm{dm}^{3}$, acidul malic $0,46 \mathrm{~g} / \mathrm{dm}^{3}$, acidul lactic $-0,32 \mathrm{~g} / \mathrm{dm}^{3}$, zahărul $-0,25 \mathrm{~g} / \mathrm{dm}^{3}$. Din punct de vedere organoleptic vinul roșu sec de masă se caracterizează printr-o extracție intensă şi astringentă. În buchetul vinului tânăr domină nuanțe de fructe de pădure. 


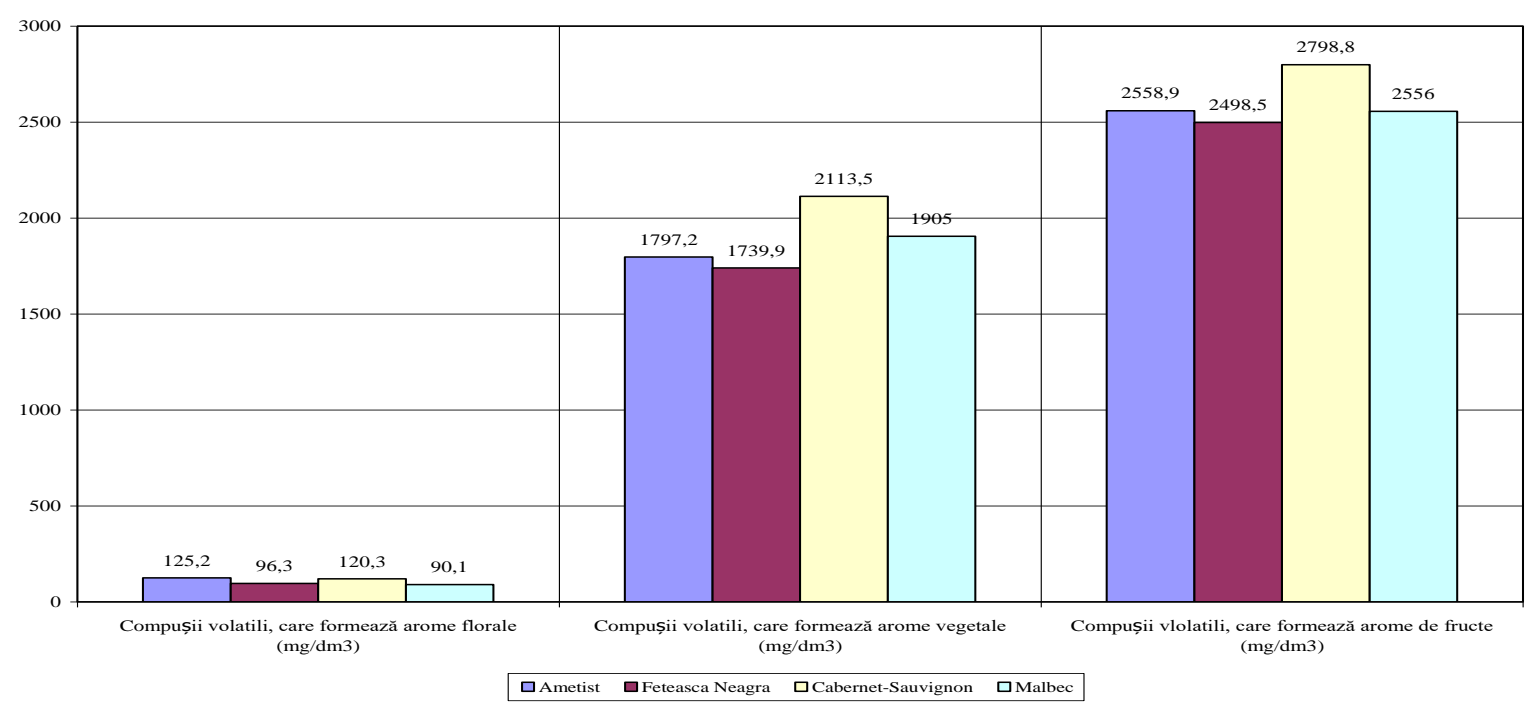

Fig. 1. Spectrul aromatic al bacelor de viţă-de-vie de culoare albastru-violet.

Reieşind din cele menţionate, constatăm faptul că spectrul aromatic al genotipului interspecific Ametist (Republica Moldova), nu se deosebeşte esenţial în comparaţie cu genotipurile intraspecifice ca: Feteasca neagră (Republica Moldova), Cabernet-Sauvignon şi Malbec (Franţa), cedând neesenţial în raport cu ultimele două soiuri la capitolul intensităţii nuanţelor vegetale şi de fructe (fig. 1.).

Analiza spectrului aromatic al bacelor de viţă-de-vie evaluate ne permite să constatăm, că în toate mostrele domină arome cu nuanţe bine exprimate de fructe.

\section{Concluzii}

1. Schimbările factorilor climatici la nivel global, în deosebi procesul de încălzire a Terrei, ne impune să revedem principiile, asortimentul şi arealele de cultivare a viţei-de-vie.

2. Analiza chimică efectuată permite a constata, că: spectrul aromatic al bacelor genotipului interspecific Ametist puţin ce se deosebeşte de cel al bacelor soiurilor intraspecifice, ca: Cabernet-Sauvignon, Malbec şi Feteasca Neagră.

3. Cantitatea şi calitatea compuşilor chimici aromatici a bacelor genotipului interspecific rizogen Ametist a fost moştenit de la forma parentală Vitis vinifera $\mathrm{L}$.

4. Genotipul interspecific rizogen de viţă-de-vie Ametist poate fi cu succes utilizat în procesul de creare a plantaţiilor de viţă-de-vie ecologice, precum şi în procesul de creare a noilor genotipuri de viţă-de-vie.

Cercetările au fost realizate în cadrul proiectului Programului de Stat 20.80009.5107.03 "Valorificarea eficientă a resurselor genetice vegetale și biotehnologiilor avansate în scopul sporirii adaptabilității plantelor de cultură și schimbările climatice”, finanțat de Agenția Națională pentru Cercetare și Dezvoltare.

\section{Bibliografie}

1. ALEXANDROV, E., BOTNARI, V., GAINA, B. Soiuri interspecifice rizogene de viţă-de-vie. Particularităţi de cultivare. Chișinău: S.n. (Tipogr. Print Caro), 2020. 99 p.

2. ANTOCE, OANA ARINA. Oenologie. Chimie și analiza senzorială. Craiova: Universitaria, 2007. 810 p.

3. ARTUR, S. Peters. Wine: types, production, and health. New York: Nova Science Publishers, 2012. 500 p.

4. BOUlTON, R., SINGLETON, V., BISSON, L et al. Principles and Practices of Winemaking. Davis - Universsity of California. Ed. Springer Science\& Business. 17.04.2013, 604 p.

5. GAINA, B. (et. al.). Uvologieșioenologie. Chișinău. Ed. AȘM, 2006. 444 pag.

6. Metode de analiză în domeniul fabricării vinurilor. Reglementări tehnice. În: Monitorul Oficial, Nr. 164-165 din 04.10.2011. Hotărârea GRM nr. 708 din 20.09.2011.

7. RIBEREAU-GAYON, M. P. Wine flavour. In: Flavour of Food and Beverages. AcademicPress, New-York, 1998, 370 p.

8. ȚÂRDEA, C. Chimia și analiza vinului. Iaşi: Ion Ionescu de la Brad, 2007. 1400 p.

9. ГАИНА, Б.С. Энология и биотехнология продуктов переработки винограда. Кишинев. Изд. Штиинца, $1992,210 \mathrm{ct}$.

10. Сборник международных методов анализа спиртных напитков, спиртов, водок и ароматической фракции напитков. Москва: Пищепромиздат, 2001. 332 с. 